UDK 378.018.43:004.738.5

DOI: $10.18524 / 2413-9998 / 2019.1(41) .173510$

\author{
Sohail Imran Khan, \\ Assistant Professor, \\ Department of Business Administration, \\ Lebanese French University \\ Kurdistan Region, Erbil - Iraq \\ e-mail: sohailkhan@lfu.edu.krd \\ Nabaz Nawazad Abdullah, \\ Head of Department, \\ Department of Business Administration, \\ Lebanese French University \\ Kurdistan Region, Erbil - Iraq \\ e-mail: nabaz@lfu.edu.krd
}

\title{
THE INFLUENCE OF SOCIAL MEDIA ON STUDENT'S ACADEMIC PERFORMANCE: A CASE STUDY OF LEBANESE FRENCH UNIVERSITY
}

Today's generation is of Networking. It is amazing to look how Internet is changing the lives of people. Social Networking is an international trend, and has spread its wings and has reached to that limit where we can find anyone from any part of the world and gain ample knowledge relating to anything. Social Media primarily originated to be connected with family and friends, but later it was adopted by business as well, as it wanted to take advantage of new and popular method of reaching to customer. On the same lines, students adopted Social Media to be in touch with colleagues and teachers as there is faster flowing of information and knowledge. The intensity of Social Media lies in its capacity to share information and connect with everyone simultaneously with everyone on the earth. The present investigation attempts to go around the impact of Social Media and understudies execution. For data collection, survey method was used with the help of structured questionnaire. The sample size was 63. Students from different year were used as respondents. SPSS-22 was used for analyzing the data. The study concluded with the study of positive and negative influence of Social Media. The positive effect includes easy passage of Information, completion of homework \& assignments and finally it encourage the academic exercise and facilitate with others. The negative effect includes that the students get dependent on it, their performance has decreased with the more use of Social Media and finally it is a distracting element.

Keywords: academic performance; social media; students.

Introduction. Social Media based life is assuming a critical job among the young. These days it is impossible to find youth without in touch of So- 
cial Media especially among the students. Social Media allows communication with your besties, colleagues easily and very effectively. Therefore, this system is called as Social. Through Social Media, we get variety of news and knowledge. Students largely use this media. Social Media platform like twitter, Facebook, YouTube, WhatsApp, Skype, WeChat, Snapchat, Viber, Instagram, etc are highly used. Educational life of a student has completely transformed since the inception of Social Media. The Social Media usage by students has the ability to affect the grades both positively and negatively. On one hand, the students can search Information through internet whenever they want and on other hand, they can communicate with their fellow students and teachers by connecting them through Social Media. Thus, the time spending on Internet and Social Media is increasing day by day. These can imaginative a positive and negative impact on the understudies' life of students.

A students' scholarly act is estimated by the aftereffect of the examination in which he/she has appeared. As the students are spending a large time on Social Media, there is a major swing in the academic performance of the students. Some students are doing extremely well while some students are not performing well in their studies. Hence, this research work was undertaken to know what influence the social media is doing on studying performance of the students. The researchers are interested to know whether social media is responsible for this swing in the scholarly execution of the understudies or not. Therefore, the researchers are interested to know the positive and negative influence of Social Media on the scholastic execution of the understudies. Therefore, the first objective of this research study is to know the positive influence of Social Media on academic performance of the students and the second objective is to know the negative influence of Social Media on academic performance of the students. This exploration work is relied upon to break down the upsides and downsides of web based life on the understudies' life.

\section{Hypothesis for Study}

1. There is no significant contrast between the beneficial outcomes of Social Media on the students' performance.

2. There is no significant distinction between the negative effects of Social Media on the students' performance.

Analysis of recent research and publications. The examination on Social Media and its influence on performance of students usually focus on many dimensions. Ample investigations have been finished so far to comprehend the effect on the students' academic performance of Social Media. 
Owen,(2008) explained that in the last two decades, Internet has uncovered the general public to new and better way of information transmit and it has quickly created methods of conveying. Likewise many researchers revealed that students are now more exposed to smart android phones and Internet and concluded that rapidly technology in penetrating in the society and among the students Eijaz (2013); Prabhu and Madan Mohan (2014). Coyle and Vaughn (2008) pointed out that web sites of social network has increased the methodology and correspondence for young users like, Facebook, Whatsapp, Viber, Snapchat, etc. Some researchers found that there could be dual influence of Social Media. The astute utilization of social media can give a huge push in student's life. Otherwise, it will be a waste of time and money. Li, Y. (2011); Madan Mohan and Prabhu (2013). Mehmood and Taswir, together in the year - 2013 pointed out that the utilization of Internet and Social Media is an imperative factor that influence the academic performance both positively and negatively in students.

\section{Positive Side of Social Media}

DeBell and Chapman (2006) conducted a survey on US students and pointed out that the students are the dense user of computer and Internet. The principle utilization of Cyberspace by the students is for communicating and coordinating with fellow students and connecting with the teachers. The students complete their assignment and get all official announcements through social media. Emeka and Nyeche (2016) together conducted a study in University of Abuja - Nigeria, titled "Impact of Internet usage on Academic Performance of undergraduate students" and used questionnaire method to collect primary data. Their finding proved that Internet is essential tool for students to increase their skills, capabilities, completing assignment, improved communication, access Information, which assist them to enhance their performance academically. Zahid, et al (2016) studied on the developing utilization of Social Media on the scholastic execution of understudies of colleges and universities. 300 students randomly selected for collecting the data. Descriptive statistics was used data for analyzing the data and found positive effect of Social Media on students' performance. Menseh and Nizam (2016) conducted a research on Malaysian students and found that Social Media can own a purposeful effect on the performance of the students academically. Further, they pointed about the unusual utilization of Social Media stages by the students and suggested that the students and universities to use the platform positively for educational purpose only so that it result in positive impact on students performance. Mushtaq A. and Benraghda A. (2018) conducted a survey on 371 students of Alberoni University, Afghani- 
stan from nine faculties like medical, engineering, political science, Education etc and found negative side to be poor as compared to the positive side. He opined that social media is useful tool as it improve learning process. All necessary information is received with the help of social media. However, he also highlighted that social media is also misspend of money and time.

\section{Negative Side of Social Media}

Khan and Abdullah (2019) in their study found 3 major elements which effects the students' academic performance. These 3 elements are waste of Time, social media as distracting element and less command over language. Banquil and Chua (2009) concluded in their study that Social Media do affect the academic performance adversity and there is a drop in the grades of the students. Students invest their time and money a lot on Social Media instead of studies. Karpinski (2009) opines that user of social media devote less time to their studies in correlation of non-users and ultimately scores low GPAs. Owusu - Acheaw \& Larson (2015) conducted a research in Ghana on the polytechnic students, titled "Use of Social Media and Its Impact on Academic Performance of Tertiary Institution Students: A Study of Students of Koforidua Polytechnic, Ghana" and found that almost all students access the variety of social media through their smart phones and spend almost 30-45 minutes a day. The study further revealed that direct connection exist between the use of Social Media and students' academic performance and it definitely negatively affects the students' academic performance, as students slowly get addicted to it. Hasnain, et al (2015) conducted a research in Pakistan about Social Media and students performance and found an inverse relationship between them. He added that if Social Media when utilized in an appropriate way can help the students to gain higher level of knowledge that can be used to achieve academically higher grades. Tamayo \& dela Cruz (2014) carried a survey on graduate students of Information Technology Science students at Centro Escolar University and tried to establish a connection between the students' academic performance and the use of Social Media. Their Study proved that Social Media hinder and distracts students learning and directly affects the performance. It also revealed that the students get too much involved in Social Media and use it only for the purpose chit-chatting and playing games.

Methodology. This research work is descriptive research and is purely based on the survey. For the research both type of data was used. The collection of variety of information from respondents, questionnaires was suitable for this examination work, which has enabled the researchers to get the actual and correct information from the target population. Hence, Primary data 
was collected with students using Social Media through the distribution of structured questionnaire consisting of open-ended, close-ended question and rating scale questions. The questionnaires were segregated into three sections. Section A analyzes the respondents demographic attribute, Section B analyzes about the general use of Web-based social networking in everyday life of students and Section $\mathrm{C}$ consisted of questions related to social media and researchers try to enquire about the positive and negative influence of social media on the academic performance of students. Target population was students only. The students differ from first year to final year of academic session of $2018-19$ ranging from 18 to 35 years of age. However, there is a mix of different courses and different colleges. For this research 30 number of male and 33 number of female students contributed $(\mathrm{N}=63)$. The response rate was $96.92 \%$, which was large enough to further carry out the research. Students were encouraged to provide genuine information about their experience of using social media and its influence on their studies. Secondary data was collected from research articles, publications, thesis, websites, journals, books etc. Data was analyzed using descriptive means, One way Analysis of Variance (ANOVA) via SPSS (Version 22). For choosing the respondents, Simple random sampling method was used. The sample has been taken from kurdistan region of Iraq, specifically in Erbil.

\section{Presentation of the main research material.}

\section{Section A: Demographic Attribute of Respondents}

This section consist of brief profile of students. The students demographic attribute consist of Gender, Age, Year of studying and Academic Achievement.

Table 1

Gender

\begin{tabular}{|c|c|c|c|c|}
\hline Gender & Frequency & Percent & $\begin{array}{c}\text { Valid } \\
\text { Percent }\end{array}$ & Cumulative Percent \\
\hline Male & 30 & 47.6 & 47.6 & 47.6 \\
\hline Female & 33 & 52.4 & 52.4 & 100.0 \\
\hline Total & $\mathbf{6 3}$ & $\mathbf{1 0 0 . 0}$ & $\mathbf{1 0 0 . 0}$ & \\
\hline
\end{tabular}

Source: Authors Calculation.

Table 1 shows the gender of the respondents. From the 63 respondents, majority $33(52.38 \%)$ were female, while 30 (47.61\%) were male. 
Table 2

\begin{tabular}{|c|c|c|c|c|}
\hline \multicolumn{5}{|c|}{ Age } \\
\hline Years & Frequency & Percent & $\begin{array}{c}\text { Valid } \\
\text { Percent }\end{array}$ & Cumulative Percent \\
\hline $15-20$ & 14 & 22.2 & 22.2 & 22.2 \\
\hline $21-25$ & 37 & 58.7 & 58.7 & 81.0 \\
\hline $26-30$ & 10 & 15.9 & 15.9 & 96.8 \\
\hline $31-35$ & 2 & 3.2 & 3.2 & 100.0 \\
\hline Total & $\mathbf{6 3}$ & $\mathbf{1 0 0 . 0}$ & $\mathbf{1 0 0 . 0}$ & \\
\hline
\end{tabular}

Source: Authors Calculation.

Out of the total valid sample of 63 students, majority (58.7\%) were found to be in the age range of 21 to 25 years, which means that that hidden objective to gather information from the young students is achieved. Table 2 shows that $22.2 \%$ are below the age of 20 years and $15.9 \%$ of students are in the age range of 26 to 30 years. However, the researchers were able to get response $(3.2 \%)$ from some elder students in the age range of 31 to 35 years.

Table 3

Year of Studying

\begin{tabular}{|c|c|c|c|c|}
\hline Year & Frequency & Percent & $\begin{array}{c}\text { Valid } \\
\text { Percent }\end{array}$ & Cumulative Percent \\
\hline I Year & 9 & 14.3 & 14.3 & 14.3 \\
\hline II Year & 23 & 36.5 & 36.5 & 50.8 \\
\hline III Year & 9 & 14.3 & 14.3 & 65.1 \\
\hline IV Year & 22 & 34.9 & 34.9 & 100.0 \\
\hline Total & $\mathbf{6 3}$ & $\mathbf{1 0 0 . 0}$ & $\mathbf{1 0 0 . 0}$ & \\
\hline
\end{tabular}

Source: Authors Calculation.

Data was collected from different years of students. Table 3 depicts the same. According to the table 3, from the total 63 students, $23(36.5 \%)$ were II year students and $22(34.9 \%)$ were IV year students. In addition to these, there were 9 students $(14.3 \%)$ each from I and III year. 
Academic Achievement

\begin{tabular}{|c|c|c|c|c|}
\hline $\begin{array}{c}\text { Academic } \\
\text { Achievement }\end{array}$ & Frequency & Percent & Valid Percent & $\begin{array}{c}\text { Cumulative } \\
\text { Percent }\end{array}$ \\
\hline Excellent & 14 & 22.2 & 22.2 & 22.2 \\
\hline Very Good & 19 & 30.2 & 30.2 & 52.4 \\
\hline Good & 22 & 34.9 & 34.9 & 87.3 \\
\hline Medium & 8 & 12.7 & 12.7 & 100.0 \\
\hline Total & $\mathbf{6 3}$ & $\mathbf{1 0 0 . 0}$ & $\mathbf{1 0 0 . 0}$ & \\
\hline
\end{tabular}

Source: Authors Calculation.

Table 4 indicates the academic achievement of students. It shows that most of students $(34.9 \%)$ replied that their achievement in academic in Good while least of 8 students $(12.7 \%)$ marked themselves as Medium in their academic achievement. Slightly above 22 percent students said that their achievement in academic is Excellent and again slightly above 30 percent students said that their achievement in academic is Very Good.

Section B: General Usage of Social Media in students' life

Table 5

Period of use of Social Media

\begin{tabular}{|c|c|c|c|c|}
\hline Period & Frequency & Percent & $\begin{array}{c}\text { Valid } \\
\text { Percent }\end{array}$ & $\begin{array}{c}\text { Cumulative } \\
\text { Percent }\end{array}$ \\
\hline 1 - 6 Months & 4 & 6.3 & 6.3 & 6.3 \\
\hline 6 Months-1 Year & 3 & 4.8 & 4.8 & 11.1 \\
\hline 1 - 3 Years & 10 & 15.9 & 15.9 & 27.0 \\
\hline 3 - 5 Years & 24 & 38.1 & 38.1 & 65.1 \\
\hline More than 5 Years & 22 & 34.9 & 34.9 & 100.0 \\
\hline Total & $\mathbf{6 3}$ & $\mathbf{1 0 0 . 0}$ & $\mathbf{1 0 0 . 0}$ & \\
\hline
\end{tabular}

Source: Authors Calculation.

Table 5 depicts that Social Media is used by majority of the students for more than 5 years. Close to $35 \%$ students have been using online networking since a quit long period. Just above $38 \%$ students have 3 to 5 years of expe- 
rience of using social media. 10 students of the total population have been using it for $1-3$ years. A small number of 3 are used to social media for less than a year. And only 4 students are used to Social Media for $1-6$ Months.

Table 6

Often student accessing Social Media Profile

\begin{tabular}{|c|c|c|c|c|}
\hline Frequency to Access & Frequency & Percent & $\begin{array}{c}\text { Valid } \\
\text { Percent }\end{array}$ & $\begin{array}{c}\text { Cumulative } \\
\text { Percent }\end{array}$ \\
\hline Daily & 38 & 60.3 & 60.3 & 60.3 \\
\hline Weekly & 9 & 14.3 & 14.3 & 74.6 \\
\hline Fortnightly & 5 & 7.9 & 7.9 & 82.5 \\
\hline Monthly & 11 & 17.5 & 17.5 & 100.0 \\
\hline Total & $\mathbf{6 3}$ & $\mathbf{1 0 0 . 0}$ & $\mathbf{1 0 0 . 0}$ & \\
\hline
\end{tabular}

Source: Authors Calculation.

From the table 6 it can be interpreted that greatest part of the total respondents (38) access their social media profile daily i.e., they made up $60.3 \%$ of the total respondents. However, there are students who access their profile once in a month.

Table 7

Frequency of use of Social Media (Per Day)

\begin{tabular}{|c|c|c|c|c|}
\hline Frequency of use & Frequency & Percent & $\begin{array}{c}\text { Valid } \\
\text { Percent }\end{array}$ & $\begin{array}{c}\text { Cumulative } \\
\text { Percent }\end{array}$ \\
\hline Less than an hour & 9 & 14.3 & 14.3 & 14.3 \\
\hline $1-3$ hours & 15 & 23.8 & 23.8 & 38.1 \\
\hline 4 - 7 hours & 29 & 46.0 & 46.0 & 84.1 \\
\hline 8 - 12 hours & 9 & 14.3 & 14.3 & 98.4 \\
\hline More than 12 hours & 1 & 1.6 & 1.6 & 100.0 \\
\hline Total & $\mathbf{6 3}$ & $\mathbf{1 0 0 . 0}$ & $\mathbf{1 0 0 . 0}$ & \\
\hline
\end{tabular}

Source: Authors Calculation.

Reflection of frequency of use of Social Media (Per Day) is shown in the table above. It reflects that close to $50 \%$ respondents are using Social Media for 4-7 Hours daily. 
Using mobile phone to access Social Media

Table 8

\begin{tabular}{|c|c|c|c|c|}
\hline $\begin{array}{c}\text { Use of Mobile } \\
\text { Phone }\end{array}$ & Frequency & Percent & $\begin{array}{c}\text { Valid } \\
\text { Percent }\end{array}$ & Cumulative Percent \\
\hline Yes & 60 & 95.2 & 95.2 & 95.2 \\
\hline No & 3 & 4.8 & 4.8 & 100.0 \\
\hline Total & $\mathbf{6 3}$ & $\mathbf{1 0 0 . 0}$ & $\mathbf{1 0 0 . 0}$ & \\
\hline
\end{tabular}

Source: Authors Calculation.

Almost all students access Social Media on their smart phone and very few $(4.8 \%)$ do not access it through their mobile phones.

Table 9

\section{Preference of Type of Social Media}

\begin{tabular}{|l|c|c|}
\hline \multicolumn{1}{c|}{ Type of Social Media } & Sum & Rank \\
\hline Facebook & 24.00 & 2 \\
\hline Messenger & 16.00 & 4 \\
\hline Instagram & 32.00 & 1 \\
\hline Flickr & 1.00 & 9 \\
\hline Twitter & 7.00 & 6 \\
\hline Myspace & 1.00 & 9 \\
\hline YouTube & 12.00 & 5 \\
\hline WhatsApp & 7.00 & 6 \\
\hline Viber & 17.00 & 3 \\
\hline Snapchat & 24.00 & 2 \\
\hline WeChat & 3.00 & 8 \\
\hline Skype & 4.00 & 7 \\
\hline LINE & 0.00 & 10 \\
\hline Any Other & 0.00 & 10 \\
\hline
\end{tabular}

Source: Authors Calculation. 


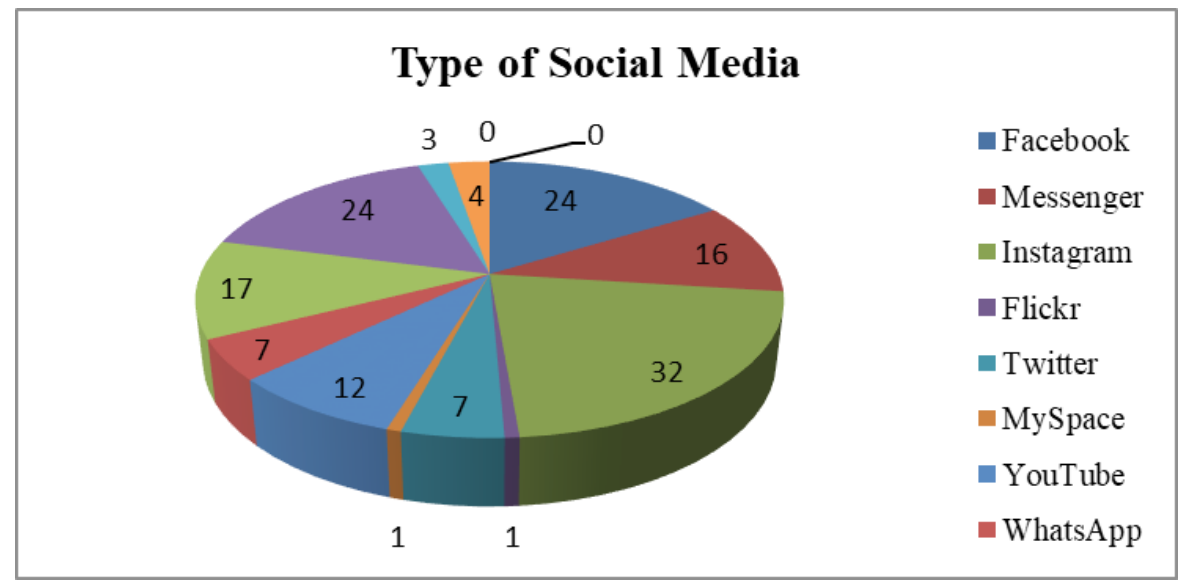

Fig.1. Type of social media

Source: Composed by authors.

When it comes to looking at which is the most prefer platforms for the students to us, here the students mostly used Instagram (fig. 1). Thus, for Social Media, Instagram ranks first in the utilization of it followed by Snapchat and Facebook. Viber ranks third in the preference of using Social Media. However, it was found that Flickr and Myspace was used by very less students and no students use LINE.

Table 10

Use aims of Social Media by Students

\begin{tabular}{|l|c|c|}
\hline \multicolumn{1}{|c|}{ Factors } & Sum & Rank \\
\hline Connecting with teachers & 5.00 & 5 \\
\hline Gathering Academic Information & 17.00 & 2 \\
\hline Keeping in touch with family and friends. & 31.00 & 1 \\
\hline For fun and entertainment & 16.00 & 3 \\
\hline Keeping you updated. & 13.00 & 4 \\
\hline Messaging & 16.00 & 3 \\
\hline
\end{tabular}

Source: Authors Calculation. 


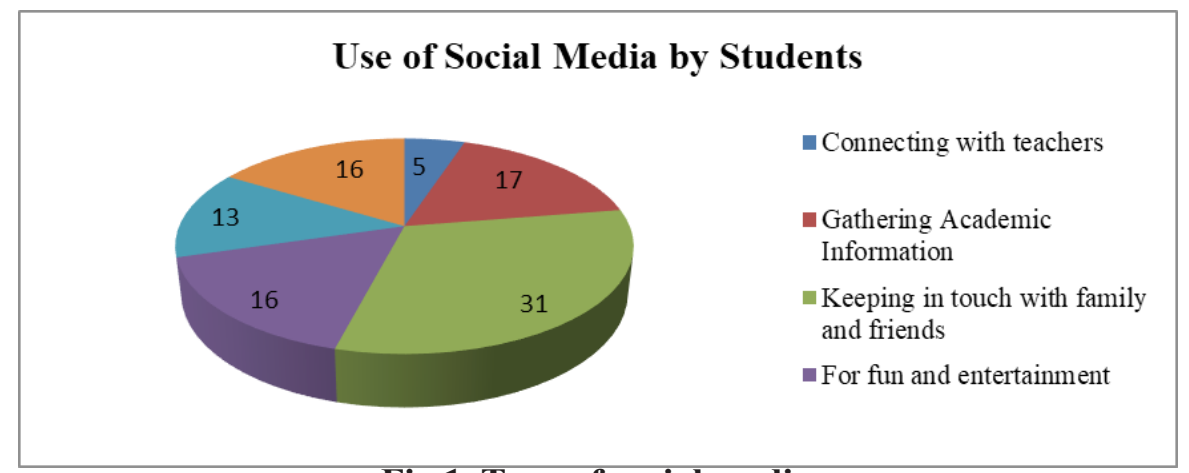

Fig.1. Type of social media

Source: Composed by authors.

Table 10 and fig. 2 illustrates the utilization of Social Media by the understudies. The students use $(\mathrm{N}=31)$ Social Media mostly to remain connected with their family and friends, secondly to get academic information from others and thirdly for Messaging and For \& Entertainment. However, the least use of social media is being in touch with the teachers.

\section{Section C: Social Media and Students Academic Performance}

This section consists of positive and negative effects of Social Media and Students Academic Performance. Students were gotten some information about positive and negative effects of Social Media with questions of 5 point Likert Scale Type varying from Strongly Agree $=5$ to Strongly Disagree $=1$.

Positive effects of Social Media and Students Academic Performance.

Students where asked about their opinion of positive effect of Social Media on their academic performance.

Table 11 reveals the mean and standard deviation of each of the questionnaire items. Serial number 3 relating to passing and receiving information is being highest weighted mean scores $(\mathrm{M}=3.68$ and $\mathrm{SD}=1.05)$. Sr. No 2 concerning with completion of assignments and homework got second best mean score $(\mathrm{M}=3.55$ and $\mathrm{SD}=1.07)$. Third highest mean score $(\mathrm{M}=3.53$ and $\mathrm{SD}=1.13$ ) is of Sr. No 5 which implies Social Media encourage the academic exercise and facilitate with others. The least mean score $(\mathrm{M}=3.34$ and $\mathrm{SD}=1.24$ ) is of Sr. No.1. It says that Social media is least used by students for receiving materials and announcement from teachers. However, the second last mean score $(\mathrm{M}=3.49$ and $\mathrm{SD}=1.09)$ implies that social media is helpful to improve communication. These findings imply how useful the 
online networking is in the life of a student. In this manner, it will help the students to achievements some good in academics.

Table 11

\section{Descriptive Statistics}

\begin{tabular}{|c|l|c|c|c|}
\hline Sr. No & \multicolumn{1}{|c|}{ Positive effects of Social Media } & N & Mean & Std. Deviation \\
\hline 1. & $\begin{array}{l}\text { Social Media help me in my studies since I can } \\
\text { get all required material and important } \\
\text { announcements from our teachers. }\end{array}$ & 63 & 3.3492 & 1.24640 \\
\hline 2. & $\begin{array}{l}\text { I complete my assignment and homework with the } \\
\text { use of Social Media. }\end{array}$ & 63 & 3.5556 & 1.07430 \\
\hline 3. & $\begin{array}{l}\text { Information is very easily passed and received } \\
\text { with the help of Social media. }\end{array}$ & 63 & 3.6825 & 1.05991 \\
\hline 4. & $\begin{array}{l}\text { Social Media helps me to improve communication } \\
\text { between my classmates and teachers. }\end{array}$ & 63 & 3.4921 & 1.09062 \\
\hline 5. & $\begin{array}{l}\text { Social Media encourage the academic exercise } \\
\text { and facilitate with others. }\end{array}$ & 63 & 3.5397 & 1.13344 \\
\hline & Valid N (listwise) & $\mathbf{6 3}$ & & \\
\hline
\end{tabular}

Source: Authors Calculation.

With an intention of evaluation the positive effects of Social Media on the academic performance of students subsequent Hypothesis was framed.

H01: There is no significant contrast between the beneficial outcomes of Social Media on the students' performance.

Table 12

\section{Descriptive}

\begin{tabular}{|c|c|c|c|c|c|c|c|c|}
\hline \multicolumn{9}{|c|}{ Positive Effects of Social Media } \\
\hline & \multirow[b]{2}{*}{$\mathrm{N}$} & \multirow[b]{2}{*}{ Mean } & \multirow[b]{2}{*}{$\begin{array}{c}\text { Std. } \\
\text { Deviation }\end{array}$} & \multirow[b]{2}{*}{$\begin{array}{l}\text { Std. } \\
\text { Error }\end{array}$} & \multicolumn{2}{|c|}{$\begin{array}{l}95 \% \text { Confidence } \\
\text { Interval for Mean }\end{array}$} & \multirow[b]{2}{*}{ Minimum } & \multirow[b]{2}{*}{ Maximum } \\
\hline & & & & & $\begin{array}{l}\text { Lower } \\
\text { Bound }\end{array}$ & $\begin{array}{l}\text { Upper } \\
\text { Bound }\end{array}$ & & \\
\hline $\begin{array}{l}\text { Strongly } \\
\text { Disagree }\end{array}$ & 2 & 1.8000 & .56569 & .40000 & -3.2825 & 6.8825 & 1.40 & 2.20 \\
\hline Disagree & 8 & 3.1500 & .75404 & .26659 & 2.5196 & 3.7804 & 2.20 & 4.20 \\
\hline Neutral & 29 & 3.5103 & .60613 & .11255 & 3.2798 & 3.7409 & 1.80 & 4.60 \\
\hline Agree & 19 & 3.6842 & .57471 & .13185 & 3.4072 & 3.9612 & 2.40 & 5.00 \\
\hline $\begin{array}{l}\text { Strongly } \\
\text { Agree }\end{array}$ & 5 & 4.2800 & .43818 & .19596 & 3.7359 & 4.8241 & 4.00 & 5.00 \\
\hline Total & 63 & $\mathbf{3 . 5 2 3 8}$ & .71521 & .09011 & $\mathbf{3 . 3 4 3 7}$ & 3.7039 & 1.40 & 5.00 \\
\hline
\end{tabular}

Source: Authors Calculation.

$\mathrm{H}_{01}$ : There is no significant difference between the positive effects of Social Media on the students' academic performance. Hence, the Hypothesis is not accepted and alternative hypothesis is accepted. 
Table 13

ANOVA

\begin{tabular}{|l|c|c|c|c|c|}
\hline \multicolumn{7}{|l|}{ Positive Effects of Social Media } \\
\hline & Sum of Squares & df & Mean Square & F & Sig. \\
\hline $\begin{array}{l}\text { Between } \\
\text { Groups }\end{array}$ & 10.414 & 4 & 2.604 & 7.089 & .000 \\
\hline $\begin{array}{l}\text { Within } \\
\text { Groups }\end{array}$ & 21.300 & 58 & .367 & & \\
\hline Total & $\mathbf{3 1 . 7 1 4}$ & $\mathbf{6 2}$ & & & \\
\hline
\end{tabular}

Source: Authors Calculation.

Table 13 reflects the overall significance, which suggests that the variables are statistically significant as the p-value is under 0.05 . The true means of the group are different. This significance test gives a passport to interpret the difference between the means, which shows the difference is real. Hence, we will not accept and reject the null Hypothesis and accept the alternative hypothesis.

\section{Negative effects of Social Media and Students Academic Perfor- mance.}

With an objective to know the negative effect of Social Media on the academic performance of students, 5 things were made in the survey.

Table 14 manifests the mean and standard deviation of each items of the questionnaire. Item number 5 relating to dependence to social media affects the students' academic performance scored the highest score mean $(\mathrm{M}=3.38$ and $\mathrm{SD}=1.27$ ). It directly implies that with the high use of Social Media students get addicted to it and negatively affect the studies of students. The next high score $(\mathrm{M}=3.30$ and $\mathrm{SD}=0.96)$ of Sr. No 4, implies the decrement in academic performance after the use of Social Media. The third highest mean score $(\mathrm{M}=3.04$ and $\mathrm{SD}=0.99)$ is about distraction from studies with the use of Social Media. However there is slight difference between the third and fourth mean score $(\mathrm{M}=3.03$ and $\mathrm{SD}=1.13)$. It says that Instead of using Social Media for leaning purpose students it for Chit-chatting and Playing Online Games. The least mean score $(\mathrm{M}=2.92$ and $\mathrm{SD}=1.14)$ is of Sr. No.1. It says that Social media is waste of money and time. This implies that students do consider Social Media as waste of money and time but it is of least effecting factor in the series. 


\section{Descriptive Statistics}

\begin{tabular}{|c|l|c|c|c|}
\hline Sr. No & \multicolumn{1}{|c|}{ Negative effects of Social Media } & N & Mean & $\begin{array}{c}\text { Std. } \\
\text { Deviation }\end{array}$ \\
\hline 1. & $\begin{array}{l}\text { Social Media requires spending } \\
\text { of money and it wastage of time, } \\
\text { therefore it affect my academic } \\
\text { performance. }\end{array}$ & 63 & 2.9206 & 1.14020 \\
\hline 2. & $\begin{array}{l}\text { Instead of using Social Media for } \\
\text { leaning purpose, I often use it for } \\
\text { Chit-chatting and Playing Online } \\
\text { Games. }\end{array}$ & 63 & 3.0317 & 1.13547 \\
\hline 3. & $\begin{array}{l}\text { Social Media distract me from } \\
\text { studies and hence affect my academic } \\
\text { performance negatively. }\end{array}$ & 63 & 3.0476 & .99074 \\
\hline 4. & $\begin{array}{l}\text { There is a decrement in my academic } \\
\text { performance after I use more of } \\
\text { Social Media. }\end{array}$ & 63 & 3.3016 & .96110 \\
\hline 5. & $\begin{array}{l}\text { Dependence to social media is } \\
\text { troublesome issue that affects the } \\
\text { students' academic performance. }\end{array}$ & 63 & 3.3810 & 1.27543 \\
\hline Valid N (listwise) & $\mathbf{6 3}$ & & \\
\hline
\end{tabular}

Source: Authors Calculation.

With an intention of evaluation the negative effects of Social Media on the students' academic performance subsequent Hypothesis was framed.

H02: There is no significant distinction between the negative effects of Social Media on the students' performance.

$\mathrm{H}_{02:}$ There is no significant difference found between the negative effects of Social Media on the academic performance of students. Hence, the Hypothesis is accepted and the Alternative Hypothesis is rejected. 
Table 15

\section{Descriptive}

Negative Effects of Social Media

\begin{tabular}{|c|c|c|c|c|c|c|c|c|}
\hline & \multirow[b]{2}{*}{$\mathrm{N}$} & \multirow[b]{2}{*}{ Mean } & \multirow[b]{2}{*}{$\begin{array}{c}\text { Std. } \\
\text { Deviation }\end{array}$} & \multirow[b]{2}{*}{$\begin{array}{l}\text { Std. } \\
\text { Error }\end{array}$} & \multicolumn{2}{|c|}{$\begin{array}{l}95 \% \text { Confidence } \\
\text { Interval for Mean }\end{array}$} & \multirow[b]{2}{*}{ Minimum } & \multirow[b]{2}{*}{ Maximum } \\
\hline & & & & & $\begin{array}{l}\text { Lower } \\
\text { Bound }\end{array}$ & $\begin{array}{l}\text { Upper } \\
\text { Bound }\end{array}$ & & \\
\hline $\begin{array}{l}\text { Strongly } \\
\text { Disagree }\end{array}$ & 2 & 3.6000 & 1.41421 & 1.00000 & -9.1062 & 16.3062 & 2.60 & 4.60 \\
\hline Disagree & 8 & 3.1750 & .50639 & .17904 & 2.7516 & 3.5984 & 2.40 & 4.00 \\
\hline Neutral & 29 & 3.0621 & .42461 & .07885 & 2.9006 & 3.2236 & 2.00 & 3.80 \\
\hline Agree & 19 & 3.1684 & .75796 & .17389 & 2.8031 & 3.5337 & 1.80 & 4.20 \\
\hline $\begin{array}{l}\text { Strongly } \\
\text { Agree }\end{array}$ & 5 & 3.2000 & 1.09545 & .48990 & 1.8398 & 4.5602 & 2.00 & 4.00 \\
\hline Total & 63 & 3.1365 & .63023 & .07940 & 2.9778 & 3.2952 & 1.80 & 4.60 \\
\hline
\end{tabular}

Source: Authors Calculation.

Table 16

ANOVA

\begin{tabular}{|l|c|c|c|c|c|}
\hline \multicolumn{1}{|l|}{ Negative Effects of Social Media } \\
\hline & $\begin{array}{c}\text { Sum of } \\
\text { Squares }\end{array}$ & df & Mean Square & F & Sig. \\
\hline $\begin{array}{l}\text { Between } \\
\text { Groups }\end{array}$ & .642 & 4 & .160 & .388 & .816 \\
\hline $\begin{array}{l}\text { Within } \\
\text { Groups }\end{array}$ & 23.984 & 58 & .414 & & \\
\hline Total & $\mathbf{2 4 . 6 2 6}$ & $\mathbf{6 2}$ & & & \\
\hline
\end{tabular}

Source: Authors Calculation.

Table 16 reflects the overall significance, which suggests that the variables are mathematically not significant as the p-value is more than 0.05 . The true means of the group are not different. This significance test gives the researchers evidence to interpret the indifference between the means, which shows the difference is no real. Hence, we accept the hypothesis.

Conclusion. Since the inception, Social Media is a huge hit especially among the students. It has attracted millions of user and it is ever increasing. Social Media is like oxygen for the students and has penetrated into every dimension of life of a student. The students of Lebanese French University are very fond of using Instagram followed by Facebook and Snapchat. The research concluded through Social Media if used effectively can lead to positive effect on the understudies' life of students. Some benefits of using 
Social Media includes that the students can easily pass and receive important information, also the students are making ample use of Social Media in completing their Assignment and Homework. Finally, Social Media encourage the students for academic exercise and facilitate with others. However as the coin have two sides; Social Media has negative sides also. Its misuse can definitely affect the academic life of a student. Here the students are getting dependent to Social Media day by day and it is increasing. Secondly, the data revealed that students' academic performance has declined after they have started using Social media. Finally, Social Media is acting as a distracting element for students. With the testing of Hypothesis, it was found that there is a significant difference between the positive effects of Social Media on the students' academic performance. Also, there is no significant difference found by the researchers between the negative effects of Social Media on the academic performance of students. Finally, we would like to conclude our research work by the fitting, adjusted and socially affirmed use of Social Media. With astuteness alongside basis considering, a lot of anything is useless. This is a well-known fact that one should be cautious when utilizing new technologies especially Social Media as it can be used both positively and negatively.

\section{Bibliography}

1. Abdullah, N. N (2018). Probing the level of satisfaction towards the motivation factors of tourism in Kurdistan Region. Scholars Journal of Economics, Business and Management. 5 (6), pp. 439-443.

2. Ahmad Mushtaq \& Abdul madjid Benraghda (2018). The effects of social media on the undergraduate students' academic performances. Library Philosophy and Practice (e-journal). Retrieved from: https://digitalcommons.unl.edu/cgi/ viewcontent.cgi?article $=5020 \&$ context $=$ libphilprac

3. Banquil, K. \& Chua, N. A. (2009). Social networking sites affects one's academic performance adversely. Retrieved from: http://www.scribd.com/doc/28919575/ SOCIAL-NETWORKING-SITES-AFFECTONE\%

4. Coyle, C. L. \& Vaughn, H. (2008). Social networking: Communication revolution or evolution? Bell Labs Technical Journal, 13 (2), pp. 13-17.

5. DeBell, M. \& Chapman, C. (2006). Computer and Internet use by students in 2003 (NCES 2006-065). US Department of Education. Washington, DC: National Center for Education Statistics.

6. Eijaz, A. (2013). Impact of new media on dynamics of Pakistan politics. Journal of Political Studies, 20 (1), pp. 113-130.

7. Emeka, U. J. \& Nyeche, O. S. (2016). Impact of Internet usage on the academic performance of under-graduates students: A case study of the University of Abuja, Nigeria. International Journal of Scientific \& Engineering Research, 7 (10), pp. 1018-1029. 
8. Hasnain, H., Nasreen, A. \& Ijaz, H. (2015). Impact of social media usage on academic performance of university students. Proceeding of 2nd International Research Management \& Innovation Conference (IRMIC). Malaysia.

9. Karpinski, A. (2009). A description of Facebook use and academic performance among undergraduate and graduate students. Annual Meeting of the American Educational Research Association, San Diego, California.

10. Khan, S. I., Sultan, A. A. \& Alsamarai, S. (2019). Social media and its adverse effect on academic performance of students. Bulletin of Social Informatics Theory and Application, 3 (1), pp. 38-44.

11. Li, Y. (2011). Survey on situation of Chinese college students choosing to use social networking. Proceedings of 3rd International Conference on Computer Research and Development (ICCRD), China. pp. 344-348.

12. Madan Mohan, G. \& Prabhu, M. (2013). A study on students perception about Facebook. International Journal of Contemporary Commerce, 1 (2), pp. 64-77.

13. Mehmood, S. \& Taswir, T. (2013). The effects of social networking sites on the academic performance of students in college of applied sciences. Int. J. Arts Commerce, 2 (1), pp. 111-125.

14. Menseh, S. O. \& Nizam, S. (2016). The impact of social media on students' academic performance: A case of Malaysia tertiary institution. International Journal of Education, Learning and Training, 1 (1), pp. 14-21.

15. Owen, H. (2008). Open space technology: A user's guide, Oakland, United States, Berrett- Koehler Publishers.

16. Owusu-Acheaw, M. \& Larson, A. G. (2015). Use of social media and its impact on academic performance of tertiary institution students: A study of students of Koforidua Polytechnic, Ghana. Journal of Education and Practice, 6 (6), pp. 94101.

17. Prabhu, M. \& Madan Mohan, G. (2014) A study on stress among university students in India. International Journal of Business and Administration Research Review, 1 (5), pp. 21-33.

18. Sultan, A. A., Noor, S. M. \& Nasirun, N. (2018). Technological factors and e-commerce adoption among small medium enterprises in Kurdistan, Iraq. Int. $J$. Eng. Technol., 7 (3.5), pp. 98-101.

19. Tamayo, J. D. \& dela Cruz, G. S. G. (2014). The relationship of social media with the academic performance of Bachelor of Science in information technology students of Centro Escolar University-Malolos. International Journal of Scientific and Research Publications, 4 (5), pp. 1-10.

20. Zahid, A., Ahmad, M., Syed, R. H. \& Faisal, H. (2016). Impact of social media of student's academic performance. International Journal of Business and Management Invention, 5 (4), pp. 22-29. 


\author{
Сохаил Имран Хан, \\ доцент факультета бизнес администрирования \\ Ливанский французский университет \\ Курдистанский район, Эрбил - Ирак \\ e-mail: sohailkhan@1fu.edu.krd \\ Набаз Хавазад Абдула, \\ декан факультета бизнес администрирования \\ Ливанский французский университет \\ Курдистанский район, Эрбил - Ирак \\ e-mail: nabaz@1fu.edu.krd
}

\title{
ВЛИЯНИЕ СОЦИАЛЬНЫХ СЕТЕЙ НА АКАДЕМИЧЕСКУЮ УСПЕВАЕМОСТЬ СТУДЕНТОВ: ПРИМЕР ЛИВАНСКОГО ФРАНЦУЗСКОГО УНИВЕРСИТЕТА
}

Современное поколение - это поколение социальных сетей. Удивительно наблюдать, как Интернет меняет жизнь людей. Социальные сети - это международный тренд, который распространяется по всему миру и достиг того уровня, когда мы можем утверждать, что нет такого человека в любой точке мира, который бы не черпал информацию из Интернета. Социальные сети, прежде всего, зародились с целью поддержания связи между семьей и друзьями, однако позднее они начал применяться и в бизнес технологиях и сегодня представляют новый популярный метод охвата клиентов. Аналогично студенты применяют социальные сети для того, чтобы поддерживать связь с коллегами и преподавателями, поскольку благодаря ним ускоряется поток информации и знаний. Интенсивность использования социальных сетей связана с их возможностью быстрого обмена информацией и одновременной связи с кем-либо в любой точке Земли. Данное исследование направлено на изучение влияния социальных сетей на академическую успеваемость студентов. В рамках исследования использовался метод сбора информации с помощью структурированного опросника. Выборка состояла из 63 студентов различных годов обучения. Программа SPSS-22 была использована для анализа данных. В рамках исследования было определено как положительное, так и отрицательное влияние социальных сетей. Положительный эффект определяется быстрым доступом к информации и выполнением домашних заданий, а также вовлечением в академическое занятие и способствует сотрудничеству друг с другом. Отрицательный эффект заключается в том, что у студентов возникает зависимость от социальных сетей: их успеваемость снижается, если увеличивается степень использования социальных сетей, и, в конечном счете, они могут быть де структивны.

Ключевые слова: академическая успеваемость; социальные сети; студенты. 


\author{
Сохаіл Імран Хан, \\ доцент факультета бізнес адміністрування \\ Ліванський французький університет \\ Курдистанський район, Ербіл - Ірак \\ e-mail: sohailkhan@lfu.edu.krd \\ Набаз Хавазад Абдула, \\ декан факультету бізнес адміністрування \\ Ліванський французький університет \\ Курдистанський район, Ербіл - Ірак \\ e-mail: nabaz@lfu.edu.krd
}

\title{
ВПЛИВ СОЦІАЛЬНИХ МЕРЕЖ НА АКАДЕМІЧНУ УСПІШНІСТЬ СТУДЕНТІВ: ПРИКЛАД ЛІВАНСЬКОГО ФРАНЦУЗЬКОГО УНІВЕРСИТЕТУ
}

Сучасне покоління - це покоління соціальних мереж. Цікаво спостерігати, як Інтернет змінює життя людей. Соціальні мережі - це міжнародний тренд, який поширюється по всьому світу та досяг того рівня, коли ми можемо стверджувати, що немає такої людини у будь-якій точці світу, яка б не отримувала інформацію 3 Інтернету. Соціальні мережі, перш за все, були створені з метою підтримки зв'язку між сім'ями та друзями, проте пізніше вони почали використовуватися і в бізнес технологіях і сьогодні представляють собою новий популярний метод охвата клієнтів. Аналогічно студенти використовують соціальні мережі для того, щоб підтримувати зв'язок з колегами та викладачами, оскільки завдяки ним прискорюється потік інформації та знань. Інтенсивність використання соціальних мереж пов'язана 3 їхньою можливістю швидкого обміну інформацією та одночасним зв'язком із будь-ким у будь-якій точці світу. Це дослідження направлено на вивчення впливу соціальних мереж на академічну успішність студентів. В рамках дослідження було використано метод збору інформації за допомогою структурованого опитувальника. Вибірка складалася з 63 студентів різних років навчання. Програма SPSS-22 була використана для аналізу даних. В рамках дослідження було визначено як позитивний, так і негативний вплив соціальних мереж. Позитивний ефект визначається швидким доступом до інформації та виконанням домашніх завдань, а також залученням до академічного заняття та сприяє співробітництву один з одним. Негативний ефект визначається тим, що у студентів виникає залежність від соціальних мереж: їхня успішність знижується, якщо підвищується ступінь використання соціальних мереж, i, в кінці-кінців, вони можуть бути деструктивними.

Ключові слова: академічна успішність; соціальні мережі; студенти. 